JURNAL INKLUSIF : Jurnal Pengkajian Penelitian Ekonomi dan Hukum Islam (Tahun 2019), Vol:4, No:2 Published by Pascasarjana IAIN Syekh Nurjati Cirebon, Indonesia. p-ISSN: 2303-2669, e-ISSN: 2548-9631

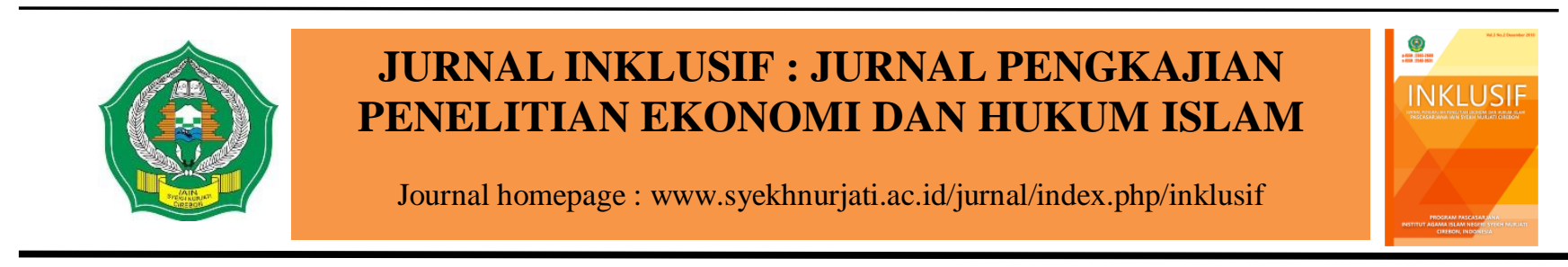

\title{
BADAN USAHA MILIK DESA (BUM DESA): TINJAUAN EKONOMI ISLAM DAN PERANNYA DALAM MENINGKATKAN KESEJAHTERAAN MASYARAKAT DESA DI KABUPATEN INDRAMAYU
}

\author{
Sufyan ${ }^{1}$ \\ Email: sufyansliyeg@gmail.com
}

Artikel info:

Received: 1 Mei 2019

Revised form: 27

Mei 2019

Accepted: 29 Mei

2019

Available online:

Desember 2019
The birth of a Village-Owned Enterprise has a connection with efforts to improve the social welfare of the community, namely the increase of all living conditions and the occurrence of a social balance of society both physically and spiritually.

The results showed that, the legal basis for the establishment of a Village-Owned Business Entity in Indramayu Regency refers to Law Number 6 of 2014 concerning Villages supported by the Village Minister Regulation Number 4 of 2015 concerning BUM Desa and later revealed in the Regional Regulation of Indramayu Regency Number 42016 concerning the Establishment and Management of Village-Owned Enterprises; The concept of empowerment in order to improve people's welfare, BUM Desa plays an important role in it. The welfare of society in the view of Islamic economics is not only measured only on matter, but also non-material; Until 2017, in Indramayu Regency there were 299 Village-Owned Enterprises engaged in the trade, production and service sectors. This is supported by available resources, including support from local governments, such as policies, funds and operations; In the implementation of Village Owned Enterprises in Indramayu district, there were no significant problems. Nevertheless, several factors that hinder the management of Village-Owned Enterprises in Indramayu Regency include: inadequate village government policies, village social and political conditions and less effective coordination between commissioners and directors; Village-owned enterprises in Indramayu Regency make a positive contribution to improving the welfare of the Indramayu community. This can be seen from the increase in income and purchasing power of the community both in the service sector, production and trade.

\section{Keywords: BUM Desa, Economy, Welfare, Society, Village}

\section{ABSTRAK}

Lahirnya Badan Usaha Milik Desa memiliki keterkaitan dengan upaya meningkatkan kesejahteran sosial masyarakat, yaitu meningkatnya segala kondisi kehidupan dan terjadinya keseimbangan sosial masyarakat baik secara jasmani maupun rohani.

Hasil penelitian menunjukan bahwa, dasar hukum berdirinya Badan Usaha Milik Desa di

\footnotetext{
${ }^{1}$ Mahasiswa Pascasarjana IAIN Syekh Nurjati Cirebon Jurusan Ekonomi Syari'ah
} 
Kabupaten Indramayu mengacu pada Undang-Undang Nomor 6 Tahun 2014 Tentang Desa yang di dukung dengan Peraturan Menteri Desa Nomor 4 Tahun 2015 Tentang BUM Desa dan kemudian diturunkan pada Peraturan Daerah Kabupaten Indramayu Nomor 4 Tahun 2016 tentang Pendirian dan Pengelolaan Badan Usaha Milik Desa; Konsep pemberdayaan dalam rangka meningkatkan kesejahteraan masyarakat, BUM Desa berperan penting didalamnya. Kesejahterakan masyarakat dalam pandangan ekonomi Islam tidak hanya diukur hanya pada materi, tetapi juga non materi; Hingga 2017, di Kabupaten Indramayu terdapat 299 Badan Usaha Milik Desa yang bergerak pada sektor perdagangan, produksi dan jasa. Hal ini di dukung oleh sumber daya yang tersedia, termasuk di dalamnya dukungan dari pemerintah daerah, seperti kebijakan, dana dan operasional; Dalam implementasi Badan Usaha Milik Desa di kabupaten Indramayu, tidak terdapat problematika yang berarti. Meskipun demikian, beberapa faktor yang menghambat dalam pengelolaan Badan Usaha Milik Desa di Kabupaten Indramayu diantaranya: kebijakan pemerintah desa yang kurang tepat, kondisi sosial politik desa dan koordinasi antara komisaris dan direksi kurang efektif; Badan Usaha Milik Desa di Kabupaten Indramayu memberikan kontribusi positif bagai peningkatan kesejahteraan masyarakat Indramayu. Hal ini terlihat dari peningkatan pendapatan dan daya beli masyarakat baik pada sektor jasa, produksi maupauan perdagangan.

\section{Kata Kunci: BUM Desa, Ekonomi, Kesejahteraan, Masyarakat, Desa}

\section{PENDAHULUAN}

Lahirnya Badan Usaha Milik Desa memiliki keterkaitan dengan upaya meningkatkan kesejahteran sosial masyarakat. Kesejahteraan dimaksud yaitu meningkatnya segala kondisi kehidupan dan terjadinya keseimbangan sosial masyarakat baik secara jasmani maupun rohani. Upaya peningkatan kondisi dimaksud dilakukan dengan membina, menumbuhkan dan mengembangkan keselarasan dalam kehidupan manusia serta dengan menciptakan kondisi lingkungan yang baik, baik secara fisik dan mental maupun kondisi sosial.

Desa menjadi bagian pemerintahan unit terkecil dari sebuah negara yang dalam prakteknya paling dekat dengan masyarakat. Secara lagsung, desa bersentuhan dengan berbagai kebutuhan masyarakat yang menuntut untuk disejahterakan. Desa sebagai wakil negara memiliki kewajiban melakukan pembangunan baik secara fisik maupun sumber daya manusia sebagai upaya meningkatkan kualitas hidup dan kehidupan serta kesejahteraan masyarakat desa yang bersangkutan.

Untuk meningkatkan hal tersebut maka dibutuhkan dua jenis pendekatan, yakni: pertama, kebutuhan masyarakat dalam melakukan berbagai perubahan sekaligus mencegah segala sesuatu yang tidak diinginkan, dan kedua, adanya political will dan juga kemampuan dari pemerintah desa secara bersama-sama dengan masyarakat dalam upaya mengimplementasikan berbagi bentuk perencanaan pembangunan yang sudah disusun sebelumnya. $^{2}$

Penelitian yang dilakukan oleh Herlina menunjukan bahwa sumbangan atau kontribusi yang diberikan Badan Usaha Milik Desa (BUMDes) kepada masyarakat berupa pinjaman dana,

\footnotetext{
${ }^{2}$ T Sugihen Bahrein, Sosiologi Pedesaan (Jakarta: Balai Pustaka, 1997).51
} 
pendidikan, dan konsultasi atau bimbingan dalam berbagai bidang sehingga kehidupan masyarakat meningkat, baik melalui usaha dagang, pertanian, maupun peternakan. Maka dari itu, dalam konteks dimaksud, Islam memperbolehkan kegiatan muamalah seperti ini. ${ }^{3}$

Keberadaan BUM Desa di Kabupaten Indramayu termasuk pengguna dana BUM Desa di berbagai bidang ternyata belum terlihat perkembangannya. Usaha masyarakat pengguna dana BUM Desa tersebut misalnya di bidang jasa pengelolaan sampah, simpan pinjam, ternak kambing dan sapi, dan PDAM Desa belum menunjukkan ada peningkatan kesejahteraan bagi masyarakatnya. Hal ini juga dipengaruhi oleh kondisi masyarakat yang masih menjadi nasabah di koperasi simpan pinjam kapitalisme yang beredar di tengah masyarakat Kabupaten Indramayu.

Optimalisasi peran Badan Usaha Milik Desa yang ada di Kabupaten Indramayu pada akhirnya diharapkan mampu meningkatkan kesejahteraan masyarakat yang dapat diukur melalui adanya peningkatan pendidikan, kesehatan dan daya beli masyarakat sebagaimana hal itu juga menjadi indikator Indeks Pembangunan Manusia (IPM). Rendahnya IPM menunjukkan kurangnya pemerataan pembangunan antar wilayah maupun antar kelompok masyarakat dalam pencapaian kesejahteraan masyarakat.

Berdasarkan pemaparan sebagaimana disebutkan di atas, peneliti merasa tertarik untuk menggali lebih jauh berkaitan dengan peranan BUM Desa dalam meningkatkan kesejahteraan masyarakat perspektif ekonomi Islam di Kabupaten Indramayu.

Adapun permasalahan dalam penelitian ini adalah dasar hukum BUM Desa, Kajian Ekonomi Islam pada pelaksanaan BUM Desa, Kondisi Objektiff BUM di Kabupaten Indramayu, problematika pengelolaan BUM di Kabupaten Indramayu, Peran BUM di dalam meningkatkan kesejahteraan.

\section{METODE PENELITIAN}

Penelitian ini menggunakan metode penelitian kualitatif sebab metode penelitian kualitatif adalah metode penelitian yang digunakan untuk meneliti pada kondisi obyek yang alamiah, dimana peneliti adalah sebagai instrumen kunci. Adapun obyek alamiah sebagaimana dimaksud adalah obyek yang terdokumentasi apa adanya, keberadaannya tidak dimanipulasi oleh peneliti sehingga kondisi peneliti pada saat memasuki obyek, setelah berada di obyek dan setelah keluar dari obyek relatif tidak berubah. ${ }^{4}$ Metode penelitian jenis ini dapat digunakan untuk memahami interaksi sosial, misalnya dengan menggunakan wawancara mendalam sehingga akan ditemukan pola-pola yang jelas tentang Badan Usaha Milik Desa (BUM Desa) di Kabupaten Indramayu.

\footnotetext{
3 Herlina, “Kontribusi Badan Usaha Milik Desa (BUMDES) Dalam Pemenuhan Kehidupan Ekonomi Masyarakat Ditinjau Menurut Ekonomi Islam (Studi Di Desa Pekan Tua Kecamatan Kempas Kabupaten Indragiri Hilir)" (Universitas Islam Negeri Sultan Syarif Kasim, 2012).

${ }^{4}$ Sugiyono, Metode Penelitian Kuantitatif Kualitatif Dan R \& D (Bandung: Alfabeta, 2013).1-2
} 
Pendekatan yang digunakan dalam penelitian ini adalah metode kualitatif dengan mengunakan pendekatan Asset Based Comunity Development ( $A B C D)$, peneliti menggunakan metode ini karena metode $A B C D$ ini mengajak kita untuk melihat pertama sebagai hadiah untuk masyarakat dari apa yang mereka inginkan, pengetahuan dan keterampilan serta sumberdaya lainnya yang kadang-kadang dapat disembunyikan, namun sering terabaikan atau diberhentikan karena tidak signifikan. ${ }^{5}$

\section{PEMBAHASAN}

Badan Usaha Milik Desa atau disingkat BUM Desa adalah suatu bentuk usaha yang dikelola oleh pemerintah desa dan masyarakat diperlukan oleh desa-desa di Indonesia sebagai sumber ekonomi untuk meningkatkan pendapatan desa serta masyarakat desa. Dalam hal ini, partisipasi masyarakat dibutuhkan baik dalam pembentukan, pelaksanaan maupun pengelolaan BUM Desa tersebut, agar hasil usaha dari BUM Desa dapat dirasakan tidak hanya oleh pemerintah desa melainkan juga masyarakat desa.

Jenis lembaga dimaksud menjadi salah satu pilar dalam pembangunan desa yang mulai digalakkan oleh pemerintah dalam rangka meningkatkan kesejahteraan masyarakat pedesaan. Sebagai sebuah sentral ekonomi desa, BUM Desa diharapkan memiliki peran dalam proses pembangunan desa yang berkelanjutan dan pemberdayaan masyarakat desa sekaligus peningkatan terhadap perekonomian desa.

Kesejahteraan merupakan satu term dari tujuan keberadaan ajaran Islam khususnya pada bidang ekonomi. Kesejahteraan merupakan bagian dari rahmatan lil alamin yang diajarkan oleh Agama Islam ini. Namun demikian, kesejahteraan sebagaimana dimaksud dalam Al-Qur'an bukanlah tanpa syarat untuk mendapatkannya. Kesejahteraan akan diberikan oleh Allah Swt jika manusia melaksanakan apa yang diperintahkan-Nya dan menjauhi apa yang dilarang-Nya. ${ }^{6}$

Konsep kesejahteraan dalam pandangan Islam setidaknya dapat dilihat pada tiga aspek, yaitu: Pertama, dilihat dari pengertiannya, sejahtera sebagaimana dikemukakan dalam Kamus Besar Indonesia adalah aman, sentosa, damai, makmur, dan selamat (terlepas) dari segala macam gangguan, kesukaran, dan sebagainya. Pengertian ini sejalan dengan pengertian "Islam" yang berarti selamat, sentosa, aman, dan damai. Dari pengertian sebagaimana dimaksud, dapat dipahami bahwa masalah kesejahteraan sosial sesungguhnya sejalan dengan misi Islam itu sendiri. Kedua, jika dilihat dari sisi kandungannya, hal ini menunjukkan bahwa seluruh aspek ajaran Islam ternyata selalu terkait dengan masalah kesejahteraan sosial. Hubungan dengan Allah misalnya, harus dibarengi dengan hubungan dengan sesama manusia. Demikian pula anjuran beriman selalu diiringi dengan anjuran melakukan amal saleh, yang di dalamnya termasuk mewujudkan kesejahteraan sosial.

\footnotetext{
${ }^{5}$ Al Barrett, Asset-Based Community Development: A Theological Reflection (Birmingham: Birmingham Vicar of Hodge Hill Church, 2013).2

${ }^{6}$ Darsyaf Ibnu Syamsuddien, Darussalaam; Prototype Negeri Yang Damai (Surabaya: Media Idaman Press, 1994). 6668
} 
Selanjutnya, ajaran Islam yang pokok (Rukun Islam), seperti mengucapkan dua kalimat syahadat, shalat, puasa, zakat, dan haji, sangat berkaitan dengan kesejahteraan sosial. Ketiga, berbagai upaya yang dilakukan dalam rangka mewujudkan kesejahteraan sosial adalah sebagian dari misi kekhalifahan yang dilakukan sejak Nabi Adam As. Sebagian pakar, sebagaimana dikemukakan H.M. Quraish Shihab dalam karyanya yang berjudul "Wawasan AlQuran", menyatakan bahwa kesejahteraan sosial yang didambakan al-Quran tercermin di Surga yang dihuni oleh Adam dan isterinya sesaat sebelum mereka turun melaksanakan tugas kekhalifahan di bumi. ${ }^{7}$

Satu diantara definisi kajian ilmu ekonomi adalah bahwa hal ini berkaitan dengan studi tentang bagaimana manusia bertingkah pekerti untuk mengorganisir kegiatan-kegiatan konsumsi dan produksinya. Oleh karenanya sistem ekonomi apapun termasuk ekonomi Islam yang diterapkan di dunia ini akan selalu berkaitan dengan tiga masalah utama perekonomian (The Three Fundamental and Interdependent Economic Problem). Ketiga masalah sebagaimana dimaksud berkaitan dengan barang apa yang dibuat, berapa jumlahnya, bagaimana cara pembuatannya dan untuk siapa distribusinya. ${ }^{8}$

Badan Usaha Milik Desa (BUM Desa) diharapkan dapat mengangkat kehidupan ekonomi masyarakat baik melalui pinjaman dana, pendidikan, konsultasi dan bimbingan yang pada akhirnya akan mampu meningkatkan kualitas hidup masyarakat sebagai masyarakat sejahtera. Kesejahteraan menurut Kamus Bahasa Indonesia berasal dari kata sejahtera yang mempunyai makna aman, sentosa, makmur, dan selamat (terlepas dari segala macam gangguan, kesukaran, dan sebagainya). ${ }^{9}$

Kesejahteraan, dalam terminologi lain, selalu dikaitkan dengan konsep kualitas hidup. Konsep kualitas hidup merupakan gambaran tentang keadaan kehidupan yang lebih baik. World Health Organization (WHO) mengartikan kualitas hidup sebagai sebuah persepsi individu terhadap kehidupannya di masyarakat dalam konteks budaya dan sistem nilai yang ada yang terkait dengan tujuan, harapan, standar, dan juga perhatian terhadap kehidupan. Konsep ini memberikan makna yang lebih luas karena dipengaruhi oleh kondisi fisik individu, psikologis, tingkat kemandirian, dan hubungan sosial individu dengan lingkungannya. ${ }^{10}$

\section{A. Dasar Hukum BUM Desa}

Undang-Undang Nomor 22 Tahun 1999 Pasal 107 ayat (1) huruf (a) menyatakkan bahwa sumber pendapatan Desa salah satunya adalah pendapatan asli desa, yang meliputi: 1) hasil usaha desa; 2) hasil swadaya dan partisipasi; 3) hasil kekayaan desa; 4) hasil gotong royong; dan 5) lain-lain pendapatan asli desa yang sah. Pada penjelasan Pasal 107 ayat (1) disebutkan bahwa pemberdayaan potensi desa sebagai upaya meningkatkan pendapatan

\footnotetext{
${ }^{7}$ Ikhwan Abidin Basri, Islam Dan Pembngunan Ekonomi (Jakarta: Gema Insani Press, 2005). 85-87

${ }^{8}$ Paul A. Samuelson dan William D. Nordhaus, Ekonomi, 12th ed. (Jakarta: Erlangga, 1989). 29-30

${ }^{9}$ W.J.S. Poerwadarminto, Kamus Umum Bahasa Indonesia (Jakarta: Balai Pustaka, 1999). 887

${ }^{10}$ Adi Fahrudin, Pengantar Kesejahteraan Sosial (Bandung: Refika Aditama, 2012). 8
} 
desa dilakukan, antara lain, dengan pendirian Badan Usaha Milik Desa, kerja sama dengan pihak ketiga, dan kewenangan melakukan pinjaman. ${ }^{11}$

Selanjutnya menurut Pasal 213 ayat (3) Undang-Undang Nomor 32 Tahun 2004 tentang Pemerintahan Daerah, yang menyatakan bahwa sebagai suatu lembaga ekonomi modal usahanya dibangun atas inisiatif masyarakat dan menganut asas mandiri. Ini berarti bahwa upaya pemenuhan modal usaha BUMDes harus berasal dari masyarakat. Badan Usaha Milik Desa, pada tataran implementasi tetap saja dimungkinkan untuk mengajukan berupa pinjaman modal kepada pihak luar, seperti dari Pemerintah Desa atau pihak lain, bahkan melalui pihak ketiga. ${ }^{12}$

Definisi lain berkaitan dengan BUMDes dapat dilihat pada Peraturan Menteri Dalam Negeri Nomor 39 Tahun 2010 Pasal 1 ayat (6) tentang Badan Usaha Milik Desa, yang menyatakan bahwa BUMDes adalah usaha desa yang dibentuk atau didirikan oleh pemerintah desa yang dalam pengelolaan maupun kepemilikan modalnya dilakukan oleh pemerintah desa dan masyarakat. ${ }^{13}$

Selanjutny BUMDes dalam Pasal 78 Peraturan Pemerintah Nomor 72 Tahun 2005 tentang Desa dinyatakan bahwa dalam rangka meningkatkan pendapatan masyarakat dan desa, Pemerintah Desa mendirikan Badan Usaha Milik Desa dimana dalam pembentukannya ditetapkan dalam Peratuan Desa dengan berpedoman pada peraturan perundang-undangan (ayat 1 dan 2). Adapun bentuknya, termaktub dalam pasal 3 yang menyatakan bahwa bentuk Badan Usaha Milik Desa harus berbadan hukum. ${ }^{14}$

Badan Usaha Milik Desa sebagaimana dimaksud merupakan suatu lembaga atau badan usaha desa yang dalam pengelolaannya secara teknis dikelola oleh masyarakat dan pemerintahan desa dalam upaya memperkuat perekonomian desa dan dibentuk berdasarkan kebutuhan dan potensi desa. BUMDes, sebagai salah satu wadah kegiatan perekonomian yang beroperasi di pedesaan diharuskan memiliki perbedaan dengan lembaga ekonomi pada umumnya. Hal Ini dimaksudkan agar BUMDes, baik dari sisi keberadaan maupun kinerja mampu memberikan kontribusi positif bagi peningkatan kesejahteraan warga desa. Selain itu, hal ini juga dimaksudkan agar tidak berkembang sistem usaha kapitalistis di pedesaan yang berakibat pada terganggunya nilai-nilai kehidupan bermasyarakat. ${ }^{15}$

Adapun tujuan utama pendirian BUM Desa adalah:

1. Meningkatkan perekonomian desa;

2. Meningkatkan pengolahan potensi desa sesuai dengan kebutuhan masyarakat;

3. Meningkatkan pendapatan asli desa;

4. Menjadi tulang punggung pertumbuhan dan pemerataan ekonomi pedesaan.

\footnotetext{
11 “Undang-Undang Nomor 22 Tahun 1999 Tentang Pemerintahan Daerah Pasal 107 Ayat (1) Huruf (A)” (n.d.).

12 “Undang-Undang Nomor 32 Tahun 2004 Tentang Pemerintahan Daerah Pasal 213 Ayat (3)" (n.d.).

13 “Peraturan Menteri Dalam Negeri Nomor 39 Tahun 2010 Tentang Badan Usaha Milik Desa Pasal 1 Ayat (6)” (n.d.).

14 “Peraturan Pemerintah Nomor 72 Tahun 2005 Tentang Desa Pasal 78" (n.d.).

${ }^{15}$ Kamaroesid Herry, Tata Cara Pendirian Dan Pengelolaan BUMDES (Jakarta: Mitra Wacana Media, 2006). 1
} 
Secara rinci, pengaturan lebih lanjut berkaitan dengan BUMDes tercantum dalam Peraturan Daerah (Perda) yang mengacu pada peraturan di atasnya. Dalam implementasinya, BUMDesa diatur melalui suatu mekanisme yang disebut self-help dan member-base, sehingga ia juga merupakan perwujudan partisipasi masyarakat desa secara keseluruhan, sehingga tidak menciptakan model usaha yang dihegemoni oleh kelompok tertentu di tingkat desa. Dengan demikian, tata aturan sebagaimana dimaksud diwujudkan melalui mekanisme kelembagaan yang solid. Penguatan kapasitas kelembagaan akan terarah pada adanya tata aturan yang mengikat seluruh anggota.

Pengelolaan BUMDes harus dijalankan dengan menggunakan prinsip kooperatif, partisipatif, emansipatif, transparansi, akuntable, dan sustainable, dengan mekanisme member-base dan self-help yang dijalankan secara profesional, dan mandiri. Dengan demikian, BUMDes yang kuat dan solid hanya akan terjadi manakala didalamnya terdapat informasi yang akurat dan tepat berkaitan dengan karakteristik ke-lokal-an, termasuk ciri sosial-budaya masyarakatnya dan peluang pasar dari produk (barang dan jasa) yang dihasilkan.

Pendirian BUMDes dilandasi oleh UU Nomor 32 tahun 2004 tentang Pemerintahan Daerah dan Peraturan Pemerintah Nomor 72 Tahun 2005 tentang Desa. Selanjutnya, dalam Undang-Undang Nomor 6 Tahun 2014 tentang Desa Pemerintah bahkan membuat satu bab khusus mengenai BUMDES. BUM Desa dapat menjalankan usaha di bidang ekonomi dan/atau pelayanan umum sesuai dengan ketentuan peraturan perundang-undangan. Peraturan Pemerintah No. 72 tahun 2005, dan diatur lebih rinci melalui Peraturan Menteri Dalam Negeri Nomor 39 tahun 2010 tentang BUM Desa.

\section{B. Kajian Ekonomi Islam pada Pelaksanaan Badan Usaha Milik Desa}

Pemanfaatan harta dalam Islam dipandang sebagai kebaikan. Kegiatan ini dilakukan untuk memenuhi kebutuhan baik jasmani maupun ruhani sehingga mampu memaksimalkan fungsi kemanusiaannya sebagai hamba Allah SWT untuk mendapatkan kebahagiaan dunia dan akhirat atau yang biasa disebut dengan Falah. Kebahagiaan di dunia berarti terpenuhinya segala kebutuhan hidup manusia sebagai makhluk ekonomi. Sedangkan yang dimaksud dengan kebahagiaan di akhirat kelak berarti keberhasilan manusia dalam memaksimalkan fungsi kemanusiaannya (ibadah) sebagai hamba Allah sehingga mendapatkan ganjaran dari Allah SWT yaitu kenikmatan ukhrawi (surga). Seseorang yang ingin mendapatkan kebahagian dunia akhirat dituntut harus mampu berjalan pada 'jalan Ilahi'. Artinya, tunduk dan patuh pada peraturan dan ketentuan yang telah Allah SWT ciptakan bersamaan dengan pelaksanaan segala aktifitas ekonomi manusia, termasuk di dalamnya ketentuan mengenai pemanfaatan harta yang dilakukan oleh umat muslim.

Dalam sistem ekonomi Islam, harta adalah materi yang kepemilikan mutlaknya berada di tangan Allah SWT dan pengelolaanya di tangan manusia, Allah SWT berfirman: 


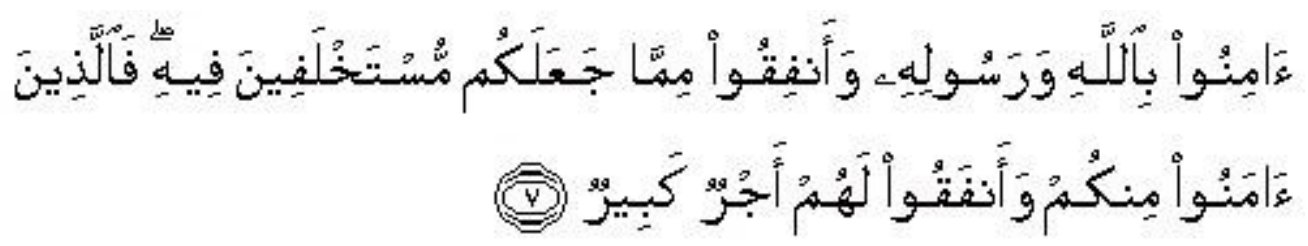

Artinya: Berimanlah kamu kepada Allah dan Rasul-Nya dan nafkahkanlah sebagian dari hartamu yang Allah telah menjadikan kamu menguasainya. Maka orang-orang yang beriman diantara kamu dan menafkahkan (sebagian) dari hartanya memperoleh pahala yang besar. ${ }^{16}$

Harta yang ada di tangan manusia pada hakikatnya kepunyaan Allah, karena Dia yang menciptakan. Akan tetapi, Allah memberikan hak kepada manusia untuk memanfaatkannya (hak pakai). Dalam Islam kepemilikan pribadi, baik atas barang-barang konsumsi ataupun barang-barang modal sangat dihormati walaupun hakikatnya tidak mutlak, dan pemanfaatanya tidak boleh bertentangan dengan kepentingan orang lain dan dengan ajaran Islam. ${ }^{17}$

Kesejahteraan menurut Islam meliputi kesejahteraan dari sisi materi dan juga non materi. Islam mengajarkan bahwasanya harta bukanlah satu satunya indikator keesejahteraan karena pada dasarnya harta hanyalah alat yang digunakan untuk tujuan beribadah kepada Allah SWT. Kata Falah sebagaimana dimaksud merujuk pada asal kata dari bahasa arab yakni kata kerja aflaha-yuflihu yang memiliki arti kesuksesan, kemenangan, dan kemuliaan, yakni kemuliaan dan kemenangan dalam hidup. ${ }^{18}$ Falah, dalam pengertian kehidupan yang mulia dan sejahtera baik di dunia maupun di akhirat, dapat terwujud jika terpenuhi kebutuhankebutuhan hidup manusia secara seimbang. Tercukupinya kebutuhan masyarakat akan memberikan dampak yang disebut dengan mashlahah.

Mahslahah sebagaimana dimaksud dalam kaitan ini adalah segala bentuk keadaan, baik material maupun non material, yang mampu meningkatkan kedudukan manusia sebagai makhluk yang paling mulia. Menurut Al-Syathibi, mashlahah dasar bagi kehidupan manusia terdiri dari lima hal yaitu agama (ad-din), jiwa (annafs), intelektual/akal (al-aql), keluarga dan keturunan (an-nasl), dan material (al-mal). Kelima hal tersebut merupakan kebutuhan dasar manusia yaitu kebutuhan mutlak harus dipenuhi agar manusia hidup bahagia di dunia dan di akhirat. Jika salah satu kebutuhan di atas tidak terpenuhi niscaya kebahagiaan hidup juga tidak tercapai dengan sempurna. ${ }^{19}$

\section{Kondisi Objektif Badan Usaha Milik Desa di Kabupaten Indramayu}

Berdasarkan Peraturan Daerah Kabupaten Indramayu Nomor 4 Tahun 2016 tentang Pendirian dan Pengelolaan Badan Usaha Milik Desa disebutkan bahwa:

\footnotetext{
${ }^{16}$ Departemen Agama, Al Quran Dan Terjemahnya (Bandung: Diponegoro, 2008).

${ }^{17}$ Veithzal Rivai \& Andi Buchari, Islamic Economics (Jakarta: Bumi Aksara, 2013). 362

${ }^{18}$ Pusat Pengkajian dan Pengembangan Ekonomi Islam, Ekonomi Islam (Jakarta: Rajawali Press, 2009). 2

${ }^{19}$ Islam.
} 
Pendirian BUMDesa dimaksudkan sebagai upaya menampung seluruh kegiatan di bidang ekonomi dan/atau pelayanan umum yang dikelola oleh Desa dan/atau kerjasama antar Desa. ${ }^{20}$

Adapun tujuan pendirian BUM Desa di Kabupaten Indramayu sebagaimana tertuang dalam peraturan dimaksud, yakni: ${ }^{21}$

1. Meningkatkan perekonomian Desa;

2. Mengoptimalkan seluruh aset Desa agar memiliki manfaat bagi kesejahteraan Desa;

3. Meningkatkan usaha masyarakat dalam pengelolaan potensi ekonomi Desa;

4. Mengembangkan rencana kerjasama usaha antar desa dan/atau dengan pihak ketiga;

5. Menciptakan peluang dan jaringan pasar yang mendukung kebutuhan layanan umum warga;

6. Membuka lapangan kerja;

7. Meningkatkan kesejahteraan masyarakat desa melalui pemerataan ekonomi Desa, pertumbuhan, dan perbaikan pelayanan umum; dan

8. Meningkatkan pendapatan masyarakat dan Pendapatan Asli Desa.

Tujuan pendirian Badan Usaha Milik Desa sebagaimana di atas, memiliki sasaran sebagai berikut:

1. Terjaminnya masyarakat di desa dalam mengembangkan usaha produktif;

2. Tersedianya media beragam usaha dalam menunjang perekonomian masyarakat desa; dan

3. Tersedianya potensi desa dan kebutuhan masyarakat.

Secara umum, hampir di setiap desa/ kelurahan yang ada di Kabupaten Indramayu memiliki Badan Usaha Milik Desa (BUM Desa). Hingga tahun 2017 tercatat ada 299 BUM Desa. Dari jumlah 299 BUM Desa yang ada di Kabupaten Indramayu, terdapat 2 (dua) BUM Desa yang tidak aktif. BUM Desa yang dimaksud adalah: 1) BUM Desa Sida Asih yang terletak di desa Sidadadi Kecamatan Haurgeulis, dan 2) BUM Desa Ki Rengas yang terletak di desa Sumbon Kecamatan Kroya. ${ }^{22}$

\section{Problematika Pengelolaan Badan Usaha Milik Desa di Kabupaten Indramayu}

Problematika dalam pengelolaan BUM Desa adalah kebijakan Pemerintah Desa yang kurang tepat yang dimaksud dalam hal ini, seperti penerapan kebijakan program BUM Desa yang tiba-tiba berubah, itu tidak lain dari pergantian jabatan kepala desa yang lama ke kepala desa yang baru. Dengan bergantinya kepala desa kebijakan juga tiba-tiba berganti dan ini

\footnotetext{
20 “Peraturan Daerah Kabupaten Indramayu Nomor 4 Tahun 2016 Tentang Pendirian Dan Pengelolaan Badan Usaha Milik Desa" (n.d.). pasal 2

${ }^{21}$ Peraturan Daerah Kabupaten Indramayu Nomor 4 Tahun 2016 Tentang Pendirian dan Pengelolaan Badan Usaha Milik Desa. Pasal 3

${ }^{22}$ Koordinator Bum Desa Kabupaten Indramayu (2017).
} 
yang menyebabkan masyarakat masih belum mengetahui dengan bergantinya kebijakan atau adanya kebijakan baru dari kepala desa yang baru.

Kebijakan yang dilahirkan pemerintah desa melahirkan suatu kontradiktif terhadap proses pengelolaan BUM Desa. Kebijakan tersebut lahir dari Visi dan Misi dari kepala desa yang baru terpilih yang dituangkan ke dalam peraturan desa. Hal ini tentu bertentangan dengan konsep pengelolaan Badan Usaha Milik Desa yang dilahirkan oleh pihak Pemerintah Daerah Kabupaten Indramayu.

BUM Desa berjalan karena atas swadaya masyarakat setelah menghasilkan sesuatu, sehingga selanjutnya selain dana hibah yang digunakan untuk membangun atau membentuk satu Badan Usaha Milik Desa tentu biaya pengelolaan didapatkan dari swadaya masyarakat, itulah konsep pengelolaan BUM Desa yang secara normatif harus dijalankan. Namun diakhirakhir ini biaya pengelolaan ini tidak lagi dibebankan kepada masyarakat tapi kepada Pemerintah Desa atas dasar perjanjian masyarakat melalui Visi dan Misi kepala desa yang baru yang dituangkan kedalam bentuk peraturan desa. Tentu dalam hal ini masyarakat tidak dapat dipersalahkan sepenuhnya karena kebijakan tersebut lahir dari pemikiran kepala desa yang baru dengan membuatkan peraturan desa yaitu peraturan Desa. Namun niat baik pemerintah desa tersebut dalam hal ini kepala desa berdampak negatif terhadap pengeloaan BUM Desa yang akhirnya berhenti beroperasional. Seharusnya kebijakan pemerintah desa ini dikoreksi kembali demi kebaikan masyarakat umum tanpa memperhatikan kepentingan politik.

Kondisi Sosial politik suatu wilayah menjadi penentu dalam menjalankan suatu kebijakan atau program karena hal ini cukup berpengaruh apabila para pelaku atau pemangku kebijakan dalam wilayah tersebut tidak bersifat professional dalam menjalankan tugas dan tanggung jawabnya. Saat ini kita sangat dipengaruhi oleh kondisi sosial dan kondisi politik yang ada, apalagi dalam menjalankan kebijakan strategis tentu sangat berpengaruh bagi orang-orang yang ada dalam lingkungan tersebut.

Fenomena yang terjadi di beberapa desa di Kabupaten Indramayu sejak tahun 2016 telah terjadi pergantian kepala Desa. Dengan terjadinya pergantian kepala desa tersebut, BUM Desa tidak berjalan lagi sesuai yang diharapkan, dimana kantor BUM Desa sudah tidak digunakan lagi seperti halnya yang dilakukan kepala desa periode sebelumnya. Ini membuktikan komunikasi dan koordinasi antara komisaris dan pengelola BUM Desa sudah tidak bisa meneruskan unit usaha yang sebelumnya telah dikelola dengan baik.

Apa yang terjadi di beberapa desa di Kabupaten Indramayu tentu menjadi contoh kecil tersendiri untuk menjadi sebagai bahan pelajaran buat kita semua, yaitu kondisi sosial politik desa sangat berpengaruh terhadap pelaksanaan serta pengeloalan BUM Desa dikarenakan profesionalitas dalam pelaksanaan dan Pengelolaan BUM Desa sudah tidak lagi dikedepankan. Hal ini dikerenakan lahirnya kubu-kubu dalam pihak Direksi dan Pihak Komisaris.

Kesemua hal ini berawal dari kekecewaan beberapa kelompok terhadap hasil pemilihan kepala desa yang menjadi momok bagi pelaksanaan BUM Desa, sehingga Direksi 
dan Komisaris saling tarik menarik kepentingan. Hal ini terjadi karena kondisi politik yang memanas serta tidak disertainya dengan sikap profesionalitas dari kedua belah pihak, masingmasing mengedepankan kepentingan kelompok atau golongan tertentu tanpa mengedepankan yang utama yaitu kebutuhan masyarakat umum yang ada di Desa.

Seharusnya apa bila kedua bela pihak mengenyampingkan kepentingan golongannya dengan mengedepankan profesionalitas sebagai mitra di desa dalam pelaksanaan dan pengelolaan BUM Desa dan mengedepankan kepentingan masyarakat umum tentu hal ini tidak akan terjadi. Namun semua hal tersebut menjadi masalah tersendiri karena kedua belah pihak tidak ada yang memperhatikan hal-hal tersebut dan larut dalam masalah sosial politik yang ada di masing-masing desa.

Terjadinya pergantian kepala desa sangat berpengaruh terhadap perkembangan BUM Desa. Posisi kepala sebagai komisaris yang dijabat secara ex officio tidak mampu menjalankan kewajibannya.

Dalam pelaksanaan dan pengelolaan Badan Usaha Milik Desa terdapat satu kendala selain beberapa point di atas. Kendala dimaksud adalah faktor lain yang menghambat secara teknis, yaitu koordinasi antara komisaris dan direksi yang kurang baik atau kurang harmonis. Hal ini merupakan imbas lanjutan dari kondisi sosial politik yang ada yang mengakibatkan komunikasi antara kedua unsur tersebut berjalan kurang baik.

Koordinasi yang kurang baik inilah sehingga pemerintah daerah dalam hal ini BPMPD harus turun tangan dalam mendamaikan kedua belah pihak namun titik temu atau solusi masalah tetap tidak didapatkan. Sehingga sampai saat ini koordinasi tetap tidak berjalan sebagaimana aturan main pengelolaan BUM Desa.

Kedewasaan berperilaku dalam menjalakan kebijakan tentu sangat dibutuhkan, apalagi menyangkut kepentingan masyarakat umum. Jika koordinasi sudah tidak jalan, maka kedua belah pihak harus mencari solusi agar kepentingan masyarakat umum di desa dapat terpenuhi kembali melalui pelaksanaan BUM Desa. Apabila kedua belah pihak masih mengutamakan kepentingan masyarakat Desa tentu mereka akan berbuat semaksimal mungkin melalui BUM Desa. Jadi koordinasi diantara mereka harus dibangun kembali dengan mengedepankan tanggung jawab terhadap jabatan yang mereka emban. Hal ini karena jabatan yang mereka emban merupakan amanah dari masyarakat Desa.

\section{E. Peran Badan Usaha Milik Desa dalam Meningkatkan Kesejahteraan Masyarakat}

Pembangunan ekonomi lebih menitik beratkan kepada masyarakat miskin dan masyarakat yang kurang mampu yang mata pencahariannya sebagai petani dan usaha kecil. Maka dari itu pemerintah daerah melalui Badan Usaha Milik Desa (BUM Desa) berupaya membantu masyarakat miskin atau masyarakat yang kurang mampu, bukan saja dengan memberikan pinjaman tetapi juga memberikan pendidikan, bimbingan dan konsultasi yang berkaitan dengan usaha atau pekerjaan mereka sehari-sehari. 
Badan Usaha Milik Desa (BUM Desa) sebagai suatu lembaga ekonomi modal usahanya dibangun atas inisiatif masyarakat dan menganut asas mandiri. Ini berarti pemenuhan modal usaha BUM Desa harus bersumber dari masyarakat. Meskipun demikian, tidak menutup kemungkinan BUM Desa dapat mengajukan pinjaman modal kepada pihak pemerintah daerah.

Sejak hadirnya BUM Desa di Kabupaten Indramayu, perekonomian masyarakat mengalami perkembangan yang signifikan terhadap pembangunan Desa. Sebelum BUMDES terbentuk pemerintah setempat sudah melihat peluang-peluang yang dapat dijadikan sektor pengembangan dan pemasukan bagi BUMDES.

Sistem penyaluran dana BUM Desa ini dilakukan secara bergilir, dan sasaran utama dana BUM Desa yaitu masyarakat miskin atau masyarakat yang kurang mampu. Dimana, masyarakat yang dipilih menerima dana BUMDES harus mengikuti pelatihan untuk mengembangkan usaha yang akan dijalankan. Pelatihan ini sangat bermanfaat bagi masyarakat yang menerima dana BUM Desa, karena mereka bisa memiliki pengetahuan yang membantu mereka dalam menjalankan usaha mereka.

Sasaran utama sumbangan atau pinjaman yang diberikan BUM Desa adalah untuk mengembangkan usaha baik usaha di bidang pertanian, perternakan, dan usaha kecil lainnya yang terdapat pada masyarakat di Kabupaten Indramayu.

Selain itu, jumlah dana sumbangan atau pinjaman dari BUM Desa yang diterima masyarakat bervariasi sesuai dengan kebutuhannya. Hal ini dilakukan oleh BUM Desa sebelum menyalurkan dana tersebut, dengan cara observasi pada lapangan secara langsung.

Pada umumnya pengusaha kecil mempunyai pendidikan dasar yang rendah dan modal usaha sangat kecil, bahkan ada yang tidak mempunyai aset yang dapat mendukung kehidupannya. Untuk itu, pemerintah memberikan pendidikan melalui seminar untuk mendukung terlaksananya pinjaman BUM Desa dengan baik, dan seminar ini dilakukan sebanyak tiga kali. Seminar atau pelatihan ini diikuti oleh masyarakat yang akan menerima dana tersebut. Tujuan dari seminar ini yaitu untuk memberikan informasi atau pemahaman kepada masyarakat dalam menjalankan usahanya. Selain itu, tujuan dari seminar ini juga sebagai lintas informasi dan memberikan masukan kepada pemerintah dalam mengambil kebijakan dan pelaku usaha kecil tentang konsep dasar yang dapat dimanfaatkan dalam penyusunan strategi, kebijakan, program, dan kegiatan pembangunan ekonomi kerakyatan.

Bimbingan dan konsultasi dalam menjalankan sebuah usaha sangatlah penting, karena hal ini dapat mendukung berkembangnya suatu usaha yang hendak dijalankan. Sesuai dengan Peraturan Pemerintah Republik Indonesia Nomor 32 tahun 1998. Pengembangan dan Pembinaan sebagaimana dimaksud dalam peraturan tersebut adalah upaya yang dilakukan oleh pemerintah, dunia usaha dan masyarakat melalui pemberian bimbingan dan bantuan perkuatan untuk menumbuhkan dan meningkatkan kemampuan usaha kecil agar menjadi usaha yang mandiri, tangguh dan dapat berkembang menjadi usaha menengah.

Oleh sebab itu, itu pemerintah Kabupaten Indramayu mengadakan bimbingan dan konsultasi untuk masyarakat yang mendapatkan dana sumbangan atau pinjaman dari BUM 
Desa. Hal ini dilakukan oleh pemerintah daerah agar dana yang diterima masyarakat sesuai dengan harapan agar usaha yang dijalankan dapat berkembang. Adapun kegiatan dalam konsultasi ini, masyarakat akan menyampaikan keluhannya dalam menjalankan usahannya kepada pihak BUM Desa.

\section{KESIMPULAN}

Dasar hukum berdirinya Badan Usaha Milik Desa (BUM Desa) di Kabupaten Indramayu mengacu pada Undang-Undang Nomor 6 Tahun 2014 Tentang Desa yang didukung dengan Peraturan Menteri Desa Nomor 4 Tahun 2015 Tentang BUM Desa dan kemudian diturunkan pada Peraturan Daerah Kabupaten Indramayu Nomor 4 Tahun 2016 tentang Pendirian dan Pengelolaan Badan Usaha Milik Desa.

Konsep pemberdayaan dalam rangka meningkatkan kesejahteraan masyarakat, BUM Desa berperan penting di dalamnya. Kesejahterakan masyarakat dalam pandangan ekonomi Islam tidak hanya di ukur hanya pada materi, tetapi juga non materi. Dalam pandangan Islam, manusia dikatakan sejahtera apabila telah memenuhi kebutuhan primer (al-daruriyyah), kebutuhan sekunder (al-hajiyyah) dan kebutuhan pelengkap (al-tahsiniyyah).

Hingga 2017, di Kabupaten Indramayu terdapat 299 Badan Usaha Milik Desa yang bergerak pada sektor perdagangan, produksi dan jasa. Hal ini di dukung oleh sumber daya yang tersedia, termasuk di dalamnya dukungan dari pemerintah daerah, seperti kebiajkan, dana dan operasional.

Dalam implementasi Badan Usaha Milik Desa di kabupaten Indramayu, tidak terdapat problematika yang berarti. Meskipun demikian, beberapa faktor yang menghambat dalam pengelolaan Badan Usaha Milik Desa di Kabupaten Indramayu diantaranya: kebijakan pemerintah desa yang kurang tepat, kondisi sosial politik desa dan koordinasi antara komisaris dan direksi kurang efektif.

Badan Usaha Milik Desa di Kabupaten Indramayu memberikan kontribusi positif bagi peningkatan kesejahteraan masyarakat Indramayu. Hal ini terlihat dari peningkatan pendapatan dan daya beli masyarakat baik pada sektor jasa, produksi maupun perdagangan.

\section{DAFTAR PUSTAKA}

Bahrein, T Sugihen. Sosiologi Pedesaan. Jakarta: Balai Pustaka, 1997.

Barrett, Al. Asset-Based Community Development: A Theological Reflection. Birmingham: Birmingham Vicar Of Hodge Hill Church, 2013.

Basri, Ikhwan Abidin. Islam Dan Pembngunan Ekonomi. Jakarta: Gema Insani Press, 2005.

Buchari, Veithzal Rivai \& Andi. Islamic Economics. Jakarta: Bumi Aksara, 2013.

Departemen Agama. Al Quran Dan Terjemahnya. Bandung: Diponegoro, 2008. Fahrudin, Adi. Pengantar Kesejahteraan Sosial. Bandung: Refika Aditama, 2012.

Herlina. "Kontribusi Badan Usaha Milik Desa (BUMDES) Dalam Pemenuhan Kehidupan Ekonomi Masyarakat Ditinjau Menurut Ekonomi Islam (Studi Di Desa Pekan Tua Kecamatan Kempas Kabupaten Indragiri Hilir)." Universitas Islam Negeri Sultan Syarif 
Kasim, 2012.

Herry, Kamaroesid. Tata Cara Pendirian Dan Pengelolaan BUMDES. Jakarta: Mitra Wacana Media, 2006.

Islam, Pusat Pengkajian dan Pengembangan Ekonomi. Ekonomi Islam. Jakarta: Rajawali Press, 2009.

Nordhaus, Paul A. Samuelson dan William D. Ekonomi. 12th ed. Jakarta: Erlangga, 1989.

Peraturan Daerah Kabupaten Indramayu Nomor 4 Tahun 2016 Tentang Pendirian dan Pengelolaan Badan Usaha Milik Desa (n.d.).

Peraturan Menteri Dalam Negeri Nomor 39 Tahun 2010 Tentang Badan Usaha Milik Desa Pasal 1 ayat (6) (n.d.).

Peraturan Pemerintah Nomor 72 Tahun 2005 Tentang Desa Pasal 78 (n.d.).

Poerwadarminto, W.J.S. Kamus Umum Bahasa Indonesia. Jakarta: Balai Pustaka, 1999.

Sugiyono. Metode Penelitian Kuantitatif Kualitatif Dan R \& D. Bandung: Alfabeta, 2013.

Syamsuddien, Darsyaf Ibnu. Darussalaam; Prototype Negeri Yang Damai. Surabaya: Media Idaman Press, 1994.

Undang-Undang Nomor 22 Tahun 1999 Tentang Pemerintahan Daerah Pasal 107 ayat (1) huruf (a) (n.d.).

Undang-Undang Nomor 32 Tahun 2004 tentang Pemerintahan Daerah Pasal 213 ayat (3) (n.d.).

Undang-undang Republik Indonesia Nomor 6 Tahun 2014 tentang Desa (2014). 